\title{
IRONISKE SKRAVERINGER
}

Om Johs.V. Jensens Skovene

\section{Ole Egeberg}

Natt som slär sina lovar

kring rösternas avsked

- Hej med dig då

- Hej med dig

- Ja, hej.

Gunnar Ekelöf

\section{Rejsedagbog?}

I 1904 udkommer Johs. V. Jensens Skovene. Seks år senere indgår den i en bibliofiludgave sammen med "Forsvundne Skove", "Dolores" og "Louison" fra lntermezzo (1899). Denne konstellation fastholdes i efterfølgende udgaver. ${ }^{1}$

Fra førsteudgaven til standardudgaven sker der to forskydninger. For det første fjernes et motto, som er et monteret citat fra "Forsvundne Skove": "Alt laa langt borte, alt laa langt borte. Det, der evigt gentog sig, skulde ingensinde naas." For det andet falder et digt tilegnet "Helled Haagen" bort. Det dukker igen op i Digte 1906.

$\mathrm{Nu}$ kunne man selvfølgelig vælge at tolke motto og tilegnelse. Mottoet kunne stå som en allusion til et længselsmotiv, og digtet kunne være en reference til det aktive handlingsmenneske. Men eftersom de to tekststykker er bortraderet i standardudgaven, som er grundlaget for nærværende læsning, ville det sikkert være mere oplagt at fokusere på deres udeladelse, idet den måske er med til at tilsløre en indre, subjektiv idé. Man kan vel ligefrem hævde, at teksten rykkes ud af en fiktionalitetssammenhæng og ind $i$ en semidokumentarisk kontekst.

Skovene er et opdagelseseventyr sammensat af en række brudstykker, en mosaik af snap-shots. I den forstand er den beslægtet 
med journalistikkens efemere virkelighedsopsplitninger. Det, der ordner rejseoplevelserne i sammenhængende perspektiv er så de enkelte, dagbogslignende kapitler, efemeriderne.

Teksten indeholder ganske vist ingen bestemte datoangivelser, men forløbet er kronologisk og retrospektivt. Det alene berettiger klart nok ikke til uden videre at applicere betegnelsen dagbog på den; men der er et væld af ubestemte tidsangivelser; og et af kapitlerne bærer endda overskriften "Af Dagbogen". Og i en fortællerkommentar direkte henvendt til læseren understreges dagbogskarakteren: "(...) men derom i Morgen." (146) Man kan altså med rimelig gyldighed placere teksten i et genreæstetisk perspektiv som en tidsforskudt dagbog. Fastholdes den forestilling lidt endnu, påberåber teksten sig en vis grad af objektivitet, og den tilføres et skær af autenticitet.

\section{Picaro på floden}

Man skal imidlertid ikke langt ind i første kapitels pseudoperigesiske optakt, før det bliver klart, at det er så som så med det autentiske og objektive. Hvad der umiddelbart fremstår som en rejseberetning, viser sig at være en gigantisk skovtur ind i en indre jungle. Refleksioner, drømme, fantasier, sansninger og idiosynkrasier spiller pieno organo i tumultariske tableauer. Det rum, fortælleren rejser $i$, bliver anledning til subjektive, introverte fragmenter. Dyr, mennesker, landskabet danner materiale for kunstnerisk produktion. Som en Picaro flintrer han rundt i den dybe jungle medbringende forvirringens kompas. Rejsen følger ikke nogen fast rute, teksten springer tilfældigt og ubesværet fra et univers til et andet. Fortælleren rejser per båd og er underlagt flodens flydende strøm af ustabil retningsorientering.

Floder og flodbilleder spiller en ikke uvæsentlig rolle, hverken i udenlandsk eller dansk litteratur, tænk f.eks. på J.P. Jacobsens To Verdener og Joseph Conrads Heart of Darkness, hvor floden i begge tilfælde optræder som stormetafor.

I Skovene kan det være svært at se floden som metafor. Måske fordi den slet ikke er det. Floden optræder in casu snarere som et narrativt element. Det er den, der konstituerer beretningens plastiske struktur. Det er den, der i sin (ud)flydende uforudsigelighed gør fortælleren til en marionet i en slags comédie à tiroirs. Det er også den lunefulde flod, der opløser enhver enhed, idet dens strøm er perpetuel, tidslig og således i stadig forandring.

Teksten standses altså ud i en række disparate, subjektive fragmenter. Alle disse fragmenter, som man mere præcist kan kalde im- 
provisationer, og som afløser og opløser hinanden i et babylonisk virvar, er skrevet på okkasioner, der er forbundet med dele af naturen, personer, sindsstemninger, selve rejseprojektet, fantasmagorier etc. Men her stopper teksten ikke, for det okkasionelle materiale sættes konstant i scene i et område, der ligger afsondret fra den empiriske totalitet, der i første omgang henvises til, nemlig litteraturens område.

\section{Skraverede blå blomster}

Allerede i første kapitels overskrift, "Birubunga", antydes den position. Birubunga er malajisk og betyder blå blomst, ${ }^{2}$ altså en allusion til længsel, noget sakralt, den romantiske digtning og hele dens register, ikke mindst Novalis Heinrich von Ofterdingen fra 1802. Navnet på fyrstendømmet udvikler sig m.a.o. fra udelukkende at henvise til en (fiktiv) geografisk lokalitet til at referere til et emblem opladet med en uendelig betydningsmængde. Den bevidsthed om at skrive sig ind $\mathrm{i}$ og op imod en intertekstualitet der kan anes allerede $\mathrm{i}$ overskriften er nok ingen tilfældighed. Overskriften virker mere som en portal, en indgang til teksten, der består af en uendelig række af citater, kommentarer, referencer og allusioner.

"Af Dagbogen" har slet ikke dagbogskarakter. Kapitlet består af en samling idiosynkratiske, projicerende udladninger konciperet $\mathbf{i}$ ensomhedens og desperationens stund. I "Credo" bekender jeg'et sig til alt fra Islam over kristendommen til kannibalisme. I "Syndefaldet" vandrer han lige lukt ind(!) i Paradis i kraft af en særdeles profan og kødelig hengivelse til luderen, Aoaaoa. Efter den omgang er der ikke meget tilbage af den oprindelige myte. De "Tigersagn", overskriften lover, er en række jagthistorier, mundtlige beretninger udfoldet $i$ et ingenmandsland mellem krostueeventyret og lystfiskerhistorien. Men med sine super-hyperboler opløser fortælleren både sagn og jagthistorier, han parodierer så at sige parodien.

Andre steder parafraseres føljetonromaner og serielitteratur ("Kampen"), heltekvad parodieres ("Tilegnelse"), Kiplings Junglebogen. citeres, reklameslogans og avisannoncer skanderes "som kunde det være fornem Poesi, jeg vil ikke sige af hvem." (98), skurrile skvadronader skråles op mod patetiske, nationalromantiske udbrud ("Uvejrsnatten" og "Aoaaoa og Lidih").

Teksten skraverer et intertekstuelt univers, men disse skraveringer er samtidig en omkalfatring af det, de henviser til. Det er en pentimenti, der bevæger sig i hele spektret fra simpel persiflage til kompliceret oversættelse, parodi. 
I sine forsøg på at skabe sammenhæng i en splintret verden, griber fortælleren tilbage til en topos; 3 men disse bevægelser fører kun til nye opløsninger. En forståelse af litteratur som et korpus af værker, hvorfra der kan hentes betydning og enhed ind i en usammenhængende og meningsløs (om)verden, negeres af fortælleren. Men hvad bliver da litteratur $\mathrm{i}$ hans selvforståelse sådan som det kommer til udtryk i Skovene? Man kunne måske lade Roland Barthes svare.

\section{Taskenspilleri}

"Ved litteratur forstår jeg den komplekse graf af praksisspor: sporene af en skrivepraksis." 4 Litteratur er altså en bestemt omgang med sproget i skriften. I litteratur er sproget til stede på en anden måde, i en anden form end i en extralitterær sproghandling.

Så snart sproget artikuleres, fusioneres det, i.flg. Barthes, med en magtinstans. Når man bruger sproget, bruger det en, det tager en på ordet. Den magt, der er indskrevet i sproget, kan kun bearbejdes af og i sproget. Disse bearbejdninger kan tage form af et spil med sprogets betydninger, og det er dette sproglige taskenspilleri Barthes kalder litteratur. Det betyder også, at den tekstuelle, litterære substans ikke er forudsat af politisk ideologiske observanser, psykiske konstitutioner, biografisk baggrund e.lign., men simpelthen af det forskydningsarbejde, der foretages i og med sproget. Det litterære $i$ en tekst er i den forstand noget, som ikke kan reduceres til udsagn eller meddelelse. Litteratur er selve sprogets iscenesættelse, skrift. Det ser ud til, at det er i et sådant perspektiv Skovene placerer sig i et intertekstuelt univers, d.v.s. i en mangfoldighed af skrivepraksisser, der ikke lader sig dechifrere entydigt, præcis som Skovene selv ikke lader sig afkode entydigt.

\section{Ironi og ekko}

Fortælleren optræder snart som storvildtjæger snart som ekspeditionsleder, på et tidspunkt er han trivialforfatter, på et andet er han muhamedaner. Det ene øjeblik boltrer han sig i en dramatisk diskurs, det andet i en lyrisk og i det næste igen i en petrarkistisk. Alle disse glidninger fra figur til figur og fra skrivemåde til skrivemåde er først og sidst semantiske. Betydningslag og -konstellationer svajer og svinger og knækker. Associationer, metaforer og konnotationer opløses i et kalejdoskopisk kaos mens teksten skrider frem. Fortælleren cirkler rundt i et omskifteligt og udbytteligt betydningslandskab. Han er, ligesom hele teksten er det, et ekko. Og hvad er så dét? 
Et ekko er tilbagekastet lyd, genlyd. Enhver, som har været på Bornholm, har helt sikkert ved den lejlighed afprøvet den med i de kredse så berømte Møller. Den lyd, eller det svar, man får tilbage, igen, forekommer umiddelbart som identisk med det, man har sagt. Men det er jo ikke det samme. Det er tværtimod noget helt andet, det kommer fra et helt andet sted, det hører ikke længere til en selv, det betyder noget helt andet. På samme måde fordobler fortælleren konstant sig selv, han producerer sig selv i nye former. Det ligner ironi.

Ironi kan ses som en udtræden af en empirisk virkelighed og en indtræden i en ironisk totalitet. Ironien opløser tiden i øjeblikke, ${ }^{5}$ hvori det ironiske subjekt får foræret en uendelig (subjektiv) frihed, idet hvert øjeblik indeholder en ny begyndelse, en mulighed. Disse øjeblikke opløser hinanden i en uendelig proces, en evig agilitet, hvorfra der altid efterlades en ny ironisk rest. Ironien er således tæt knyttet til det tidslige. Det ironiske subjekt, den ironiske fortæller har en klar bevidsthed om tiden som et destabiliserende element, tiden som relativerende instans, der gør betydningsdannelser ustabile. Der er forskel på lyd og genlyd.

\section{Ironisk skrift}

Så langt virker det vist ikke hasarderet at betragte Skovenes fortæller som et ironisk subjekt. Konstant udskilles han i nye frapperende roller, former, situationer; driblende rundt i inhomogene, skriblende, barokke, hyperboliske skrivemåder, hvori introspektive refleksioner, filosofiske og religiøse spekulationer, profane husmandsbetragtninger, parodiske lobhudlinger, patetiske deklamationer, programmatiske monologer og selvironiske præsentationer, mir nichts dir nichts, flettes ind i et diffust mønster af uvilkårlighed. Det er en famlende hybridskrift i stadig bevægelse, den spiller på, men lader sig ikke indfange af traditioner, normer og genrer:

Hvad mig angik saa paastod jeg, indtil jeg blev gendrevet, at jeg slet ikke havde været oppe $i$ Skovene eller $i$ Birubunga, men at det hele bare var et Foster af min tropiske Fantasi, som jeg havde siddet hjemme $i$ Evropa og givet en Form, der egnede sig for Subskription $i$ de tusind Hjem. (160)

Det er skriften, der skal konstituere subjektet. Men det er en ustabil, lunefuld skrift, der hverken kan stable et helt subjekt, en hel individualitet eller en hel skrift på benene. Den skrivepraksis, den skriven sig ind i og ud af junglen, jeg'et præsterer, kunne man kalde en iro- 
nisk skrift , 6 altså en uendelig ironisk akt, hvor skriften skraverer eller henviser til noget uden for sig selv, men disse skraveringer/ henvisninger unddrager sig en entydig afkodning. Det er en skrift, der er bevidst om det temporale som fundamentalt destabiliserende, en skrift, der ironisk opløser enhver unilateral betydningsdannelse, og som i de ironiske bevægelser peger på disse opløsninger.

Og hvilket andet sted end Birubunga, den blå blomsts land, har en sådan skrift bedre udfoldelsesmuligheder, hvor, om ikke i en romantisk kontekst, der længes og higer efter enhed og sammenhæng, men konstant taler om splittelse og fragmentation, kan Skovenes skrift udvikle sig?

\section{Efterskrift: Den ironiske bricoleur}

----!!!-----?

Skovene indtager i Jensen-receptionen nærmest en marginalposition. Efter Aage Schøittz-Christensens disputats (1956), har Henrik Wivel (1982) og Bent Haugaard Jeppesen (1984) som de eneste beskæftiget sig seriøst med teksten.

Henrik Wivel ser klart, at Skovene på mange måder er "et usædvanligt værk", at rejsen er en "indre opdagelsesrejse ned i det ubevidstes jungle", som har "til formål at udrydde det kvindelige, blive den ulidelige kønsdrift og natur kvit." (p.74) For Bent Haugaard Jeppesen er det driftsstyrede jeg også et imperialistisk jeg, der "som en Stanley" repræsenterer "en form for hvid mands beherskelse og katalogiserende markering af ordnede forhold i den kaotiske natur." (p.53)

Teksten læses m.a.o. som en repræsentation af psykiske hhv. politisk-ideologiske spændinger bundet til en forfatter-intention. Vist er teksten skrevet af Johs. V. Jensen, vist forekommer hans sociale og politiske holdninger ofte utålelige og vist er teksten skrevet efter en rejse til staten Tringganu på Malakkakysten; men det er en fiktiv tekst, en kunstnerisk bearbejdning, litteratur. Læses Skovene i det perspektiv, altså uden at identificere fortæller med forfatter, er det nok lettere at få øje på det (ironiske) spil, som er på spil i teksten.

Det er en bricoleur, der arbejder her. Han fusker med betydningsdannelser ved konstant at lægge op til ét og lade noget andet udvikle sig. Det er en praksis, som viser sig helt ud i tekstens yderste lag. Projektet, at dræbe tigeren og bestige Verdensbjerget, Bukitalam, opløses, det bliver en dundrende fiasko. Kampen med tigeren 
foregår i en perialiseret fantasmagori og bjerget får han kun at se på afstand. Og hans bekendelse til den moderne maskinvirkelighed $\mathrm{i}$ "Tilegnelse" er en artistisk blændende opvisning i retorisk ironi: at sige ét og mene det modsatte/noget andet. Forestillingen kan begynde på ny. Det uafsluttelige ved selve projektet gælder hele teksten. Den lader sig ikke afslutte endeligt, betydningerne fortsætter med at spille kakafonisk imod hinanden i en larmende ambivalens.

\section{Noter}

1. Standardudgaven er fra 1925 . Jeg anvender femte-udgaven fra 1953.

2. Cf. Johannes V. Jensen in Søndag. Tillæg til Dagens Nyheder 27/3 1932.

3. Jeg anvender her begrebet topik som "den skat af emner og former, der udgør traditionens og kulturens fælles ejendom." (Gerard Genette: "Strukturalisme og litteraturkritik" in Peter Madsen (red.): Strukturalisme. En antologi. Kbh. 1970, p . 109)

4. Roland Barthes: Om litteraturen. To lektioner (1985) p.15

5. Cf. Søren Kierkegaard "Om Begrebet Ironi med stadigt Hensyn til Socrates" in Samlede VærkerBd. 1, 3. udg. (1982), pp. $268 \mathrm{ff}$ og pp. 275 ff.

6. Det, jeg kalder en ironisk skrift, er vel næsten identisk med det, Jørn Erslev Andersen kalder "en sækulariseret, allegorisk skrift" i "Folianten og alferne - Jens Baggesen og H . C . Andersen på hedetur" in Dryssende roser. Essays om digtning og filosofi (1988) p. 101. Min læsning af Skovene er ikke bare inspireret af hele denne essaysamling, men står i noget nær ubetalelig gæld til den. Men med betegnelsen ironisk skrift har jeg ønsket at betone det opløsende og distancerende. Se også Paul de Man Blindness and Insight 2. udg. London (1983) - især pp. 208-28.

Litteratur om Johs. V. Jensen, jeg henviser til:

Aage Schiøttz-Christensen: Om Sammenhængen i Johannes $V$. Jensens Forfatterskab (1956; 2 . udg. 1962)

Henrik Wivel: Den titaniske eros (1982)

Bent Haugaard Jeppesen: Johannes $V$. Jensen og den hvide mands byrde (1984) 


$$
\text { Ja隹 }
$$

